\title{
Views of Social Studies Teachers on Scientific Research Methodology
}

\author{
Hüseyin Bayram*

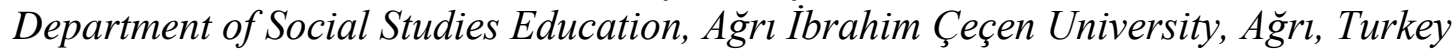 \\ ORCID: 0000-0001-6065-8865
}

\begin{tabular}{|c|c|}
\hline Article history & \multirow{9}{*}{$\begin{array}{l}\text { Scientific method is one means by which knowledge is created. The goal } \\
\text { of the social studies course is to teach the methodology used by these } \\
\text { sciences in accessing the subject information along with the information } \\
\text { they provide from social sciences. Therefore, social studies teachers } \\
\text { should be aware of the scientific research methodology so that they can } \\
\text { teach according to this purpose. In this study, the focus was on how } \\
\text { teachers consider scientific research. This study aimed to investigate } \\
\text { social studies teachers' views on scientific research methodology. It } \\
\text { adopted phenomenology, one of the qualitative research designs. } \\
\text { Maximum diversity sampling and criterion sampling were used to } \\
\text { determine the study group. Data collection consisted of two stages. In the } \\
\text { first stage, the Views about Scientific Inquiry Questionnaire (VASI) was } \\
\text { applied. The second stage included a semi-structured interview form } \\
\text { prepared by the researcher. Data were analysed via the descriptive } \\
\text { analysis technique. The codes were classified under the headings in the } \\
\text { VASI form. Findings showed that views of social studies teachers } \\
\text { regarding scientific research methodology were mostly wrong and } \\
\text { inadequate. Based on the findings, recommendations were made to social } \\
\text { studies teachers, administrators, and the officials of the Council of Higher } \\
\text { Education (CoHE). These suggestions were as follows: Teachers need to } \\
\text { learn about scientific research methodology, school administrators should } \\
\text { implement programs such as in-service training for teachers on a related } \\
\text { subject, and CoHE officials should add more content about scientific } \\
\text { research methodology to social studies teacher training programs. }\end{array}$} \\
\hline & \\
\hline $\begin{array}{l}\text { Received in revised form: } \\
01.03 .2021\end{array}$ & \\
\hline & \\
\hline Key words: & \\
\hline & \\
\hline & \\
\hline & \\
\hline & \\
\hline
\end{tabular}

\section{Introduction}

Life is in a continuous cycle. Human beings try to survive in this cycle and find solutions to the challenges they encounter. They have developed a systematic structure over time by attempting to overcome these challenges. This structure is science that includes calculations, hypotheses, and laws created within the scope of life. Although science is a phenomenon as old as human history, it has reached a clear framework with the transformation process revealed as a result of the Renaissance (15-16th Century) and Reform Movements (16th Century). It is possible to express science in the form of systematic information that humanity creates through thinking activities.

\footnotetext{
* Correspondency: hubayram@agri.edu.tr
} 
The main aim of science is to reach scientific knowledge. Scientific knowledge refers to information obtained by using rational methods and techniques in systematic thinking and application processes (Katz, 1997). Knowledge must have certain qualities for being scientifically accepted. These qualities are a-) being generalizable, b-) being cumulative, c-) being comprehensive and having a framework, and d-) being oriented towards a certain area (Büyüköztürk et al., 2010).

Scientific knowledge occurs at the end of the scientific research process. Scientific research is the investigation of the relationships between human beings and nature from a rationalist perspective (Hyland, 1998). It is also a process carried out through scientific research methods (Wilson, 1990). The variables of scientific research include observation, experimentation, and measurement techniques (Hull, 2010). Knowledge is reached through scientific research (Kaboub, 2008). In this context, researchers need to master all variables of scientific research (Crook \& Garrat, 2005). Constructivism, the dominant philosophy of education of the twenty-first century (Kim, 2001), aims to teach the concept of scientific research to students, who are the researchers of the future, starting from primary school (Chu et al., 2008) and middle school (Stokking et al., 2004). The current curricula, which have been in force at all school levels since 2005 in Turkey, have been prepared according to the constructivist education approach and designed to equip students with different skills such as observation, communication, cooperation, and problem solving as well as research skills. The social studies curriculum, which is a course taught in primary and middle schools, also aims to facilitate the skills created within the scope of constructivism. The curriculum of social studies, which is a course taught in primary and secondary schools, has been introduced within the scope of constructivism. Referring to the declaration published by the National Council of Social Studies (NCSS) in America in 1992, the 2005 Social Studies Curriculum in Turkey provides the most comprehensive definition for the social studies course. Accordingly, social studies (MEB, 2005);

"is an elementary education course that reflects the subjects of social studies such as history, geography, economics, sociology, anthropology, psychology, philosophy, political science and law, and citizenship knowledge in order to help the individual to realize his social existence; involves combining learning areas under a unit or theme; in which the interaction of human with their social and physical environment is examined in the context of past, present and future; that was created based on collective teaching."

Another comprehensive definition was made by Öztürk (2015).

"Social studies is a curriculum that combines information and methods obtained from social and human sciences to raise effective citizens who can make informed decisions and solve problems in changing country and world conditions in almost every aspect."

Both definitions (MEB, 2005; Öztürk, 2015) argue that social studies is a course that aims to transfer the knowledge of different science fields (and the scientific research methods they use to access information) to students with a collective teaching approach. The 2018 Social Studies Curriculum displays that the social studies course pays attention to scientific research. "Research by using the steps of scientific research" has been included in the curriculum for the importance given to scientific research in the field of 6th grade Science, Technology and Society learning (MEB, 2018, p.21). Regarding this outcome, the social studies course aims to teach the salient aspects of conducting scientific research to students. Social studies curriculum prepared based on constructivism positions the student as an active researcher and 
the teacher as an advisor. To realize the objectives of the course, the teacher must have full knowledge of the curriculum and be equipped with the knowledge and skills that must be possessed during the implementation of the program. Therefore, social studies teachers must internalize the concept of scientific research to transfer the knowledge of scientific research to their students as desired. Based on this requirement, this study aimed to examine the views of social studies teachers towards scientific research and to inform both school administrators and higher education institutions about how social studies teachers consider scientific research.

Studies investigating the views towards scientific research were common in science. All of the studies surveyed were found to be related to science teachers and students. Some studies examining students' views on scientific research are as follows:

Comparing the views of science students on scientific research in Turkey and the USA, SSenler (2015) used a questionnaire for data collection. American students were found to perceive the phenomenon of scientific research more accurately than Turkish students and their answers were more consistent. Similarly, Lederman et al., (2017) conducted a study with seventhgrade students from different countries and reported that students did not have consistent views on scientific research methodology. They stated that students had some incorrect or incomplete knowledge about scientific research.

Some of the studies examining teachers' views on scientific research are as follows:

Examining the views of novice middle school science teachers about scientific research, Park and Young-Isni (2010) found that teachers had consistent information about some aspects of scientific research and incomplete information about other aspects. Çiğdemoğlu and Köseoğlu (2019) held workshops to improve science teachers' views on scientific research. They interviewed teachers before and after the study and found significant improvements in their views after the implementation. A similar study conducted with science teachers was conducted by Wahbeh and Abd-El-Khalick (2014). The researchers aimed to improve teachers' attitudes and perspectives on the pedagogical dimension of scientific research by implementing a six-week intensive in-service training. Then, they observed significant improvements in teachers' attitudes towards the nature and pedagogical dimension of scientific research. Investigating the views of science teachers and student teachers on the nature of science in Spain, Vasques-Alonso and Garcia-Carmona (2013) applied pre-test and post-test to participants. After the pre-test, they implemented a program to introduce the nature of science and then used a post-test. The researchers observed a significant difference between pre-test and post-test values in favour of the post-test.

Various similar studies were conducted in science (Bianchini \& Colburn, 2000; Khishfe and Abd-El-Khalick, 2002; Leblebicioğlu et al., 2017; Lederman et al., 2014; Luehman \& Markowits, 2007; Yu \& Yang, 2010). However, there is no study examining the views on scientific research in social studies. The absence of research was seen as a gap. Therefore, this study was constructed with a view to contributing to the relevant literature and hence constitute a source for similar studies.

\section{Aim and Significance of the Study}

This study aimed to examine the views of social studies teachers, who were working in different provinces of Turkey, on scientific research methodology. The study findings are 
thought to be a resource that the Council of Higher Education (CoHE) can use while organizing training programs for social studies teachers and school administrators and more specifically when they are determining the goals of in-service training programs as such.

\section{Method}

This is a qualitative study. Therefore, the design of the study, the technique of determining the participant group, data collection tools, and data analysis method were organized in line with the nature of qualitative research. The reason for using qualitative methodology was to examine the teachers' views in depth.

\section{Design}

The phenomenological design was used. Phenomenology is preferred when the aim is to examine the existing in-depth and reflect the existing as it is (Glesne, 2016; Patton, 1990). The reason for choosing phenomenology is that teachers' views were examined in depth without any intervention.

\section{Participants}

The study group consisted of social studies teachers graduating from different universities in Turkey. Two stages were followed while recruiting the participants.

In the first stage, 391 social studies teachers working in the provinces of Istanbul, Ankara, Diyarbakır, Mardin, and Ağrı were reached, and they were asked to state the universities they graduated from. Maximum diversity sampling was adopted to ensure data source diversity. Among them, 42 teachers who graduated from different universities in seven regions of Turkey were selected. In qualitative research, maximum diversity sampling was used to reach different data types from similar data sources and to provide data diversity (Onwuegbuzie \& Leech, 2007). The reason for using the aforementioned sampling method in this study was to provide data that constitutes a relatively richer potential.

In the second stage, the criterion sampling method was used to select a group of six teachers, and they were interviewed. Some teachers did not provide clear answers and did not answer some questions. Criterion sampling helps select participant group according to certain criteria (Büyüköztürk et al., 2010). The reason for using criterion sampling was that the first data collected from the participants were not sufficiently understood by the researcher. The names of the participants and the universities they graduated from were changed within the scope of ethical rules. The researcher used pseudonymous names for participants. The universities were given numbers starting with the initials of the geographical regions where the universities were located. Marmara and Mediterranean regions consist of a single word and start with the same letter; thus, the first 3 letters of Mediterranean were used while coding universities in the Mediterranean region. Table 1 presents information about the participants.

Table 1. Demographic Information (Participants interviewed were shown in bold)

\begin{tabular}{lll}
\hline Region & University & Participants \\
\hline Southeastern Anatolia & SAU1 & Özkan, Cengiz \\
\cline { 2 - 3 } & SAU2 & Sema, Ahmet \\
\cline { 2 - 3 } & SAU3 & Ayşe, Cansu \\
\hline Eastern Anatolia & EAU1 & Ömer, Kadir \\
\cline { 2 - 3 } & EAU2 & Mehmet, Fatma \\
\cline { 2 - 3 } & EAU3 & Gönül, Gülşen \\
\hline
\end{tabular}




\begin{tabular}{lll}
\hline Central Anatolia & CAU1 & Gizem, Tarık \\
\cline { 2 - 3 } & CAU2 & Barış, Özgür \\
\cline { 2 - 3 } & CAU3 & Sevim, Zerrin \\
\hline \multirow{2}{*}{ Black Sea } & BSU1 & Ali, Çetin \\
& BSU2 & Gökhan, Sevgi \\
\cline { 2 - 3 } & BSU3 & Sahin, Osman \\
\hline \multirow{2}{*}{ Marmara } & MU1 & Mahmut, Sedat \\
\cline { 2 - 3 } & MU2 & Betül, Duygu \\
\cline { 2 - 3 } & MU3 & Meltem, İnci \\
\hline Aegean & AU1 & Selin, Sadık \\
\cline { 2 - 3 } & AU2 & Gökçe, Gamze \\
\cline { 2 - 3 } & AU3 & Derya, Dilek \\
\hline Mediterranean & MEDU1 & Hakan, Ümit \\
\cline { 2 - 3 } & MEDU2 & Ilker, Mert \\
\cline { 2 - 3 } & MEDU3 & Yavuz, Vedat \\
\hline Total & $\mathbf{2 1}$ & $\mathbf{4 2}$ \\
\hline
\end{tabular}

Three universities from each region were determined, and two social studies teachers who graduated from each university were selected. Besides, six teachers from different universities (EAU1, EAU3, CAU3, MEDU2, BSU2, and MEDU3) were interviewed. In this context, the table includes 21 universities from seven regions and 42 participants who graduated from these universities.

All social studies teacher training programs in Turkey applied the same curriculum until 2018, and they provided the course regarding the scientific research methodology (scientific research methods) only in the second year. All teachers listed in Table 1 took the pre-2018 curriculum called "old curriculum" during their undergraduate education. In this context, the fact that all participants' being exposed to the same content for scientific research methodology ensures that the participant group has an arguably homogeneous structure.

\section{Data collection}

Data were collected in two stages. In the first stage, the Views about Scientific Inquiry Questionnaire (VASI), developed by Lederman et al. (2014) and adapted into Turkish by Karışan, Bilican and Şenler (2017), was applied. It consists of 13 open-ended questions. The questions help make the person think and reveal his/her views. The form was e-mailed to all participants as a Microsoft Word file, and the participants were asked to fill it out. While analysing the forms, the expressions of some participants were found inaccessible. In this context, those participants were interviewed by using the semi-structured interview form prepared by the researcher. Thus, the researcher tried to clarify the data collected through the Views about Scientific Inquiry Questionnaire. The interview was conducted on the telephone, and it was tried to reach clear information by asking questions formed by detailing the questions in the Views about Scientific Inquiry Questionnaire.

\section{Data analysis}

The data analysis process was carried out in two stages: The analysis of the Views about Scientific Inquiry Questionnaire and the analysis of the interview data. Both analyses were combined in the findings section. Lederman et al. (2014) determined titles such as "'unclear, naive, mixed, and informed"' in VASI form. In this study, "unclear" was replaced by "false/noresponse". At this stage, the answers given by the participants were analyzed and classified under the aforementioned headings. 
In the second stage, the interview data were analysed. These data, just like data obtained from the Views about Scientific Inquiry Questionnaire, were classified under the headings mentioned above and used to clarify the data of the form. All data were subjected to descriptive analysis. The descriptive analysis includes performing the analysis process within the scope of predetermined themes (Glesne, 2016). The themes were predetermined. For this reason, descriptive analysis was used when analysing data.

\section{Validity and Reliability} the study.

The following processes were followed in order to ensure the validity and reliability of

- Expert opinions were taken before interview and experts provided the following feedback: "1-there are repetitive questions, 2- the second and fourth questions are more like quantitative research questions, 3- all questions should be checked and rewritten if necessary." The questions were revised according to the feedback received from the experts. The interview form was applied to four teachers who were not included in the study before the implementation phase of the study, then it was reviewed and finalized.

- Data were read three times during the analysis process. First, it was read superficially to get a general idea. Next, it was read for the second time, and coding was started. The researcher considered the coding process at this stage as "superficial coding process". Then, the in-depth reading phase started. At this stage, the codes created in the previous reading were checked. Unsuitable codes were eliminated, and the coding process started from the beginning. Generated codes were classified under predetermined themes in accordance with the descriptive analysis method.

- The findings of the study were reached by interpreting the codes classified under themes. The findings were presented to the expert opinions, and the opinions were taken to examine whether they coincide with the aim of the research. Within the scope of the positive feedback received from the experts, the results of the research were written and discussed.

\section{Findings}

Findings were first digitized under the themes (such as false/noresponse, naive, mixed, informed) in Table 2 . Then, each question was presented separately.

Table 2. Views of Social Studies Teachers on Scientific Research Methodology

\begin{tabular}{|c|c|c|c|c|c|c|}
\hline & $\begin{array}{ll}\text { estion } & \text { False } \\
& (\%)\end{array}$ & No response & $\begin{array}{l}\text { Naive } \\
(\%)\end{array}$ & Mixed (\%) & $\begin{array}{l}\text { Informed } \\
(\%)\end{array}$ & Total \\
\hline \multirow[b]{3}{*}{ 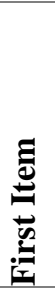 } & $\begin{array}{l}\text { Views on the basic structure of } \\
\text { scientific research (question A) }\end{array}$ & 4.76 & 7.14 & 9.52 & 78.58 & 100 \\
\hline & $\begin{array}{l}\text { Views on the basic structure of the } \\
\text { experimental process (question B) }\end{array}$ & 2.38 & 2.38 & - & 95.24 & 100 \\
\hline & $\begin{array}{l}\text { Views on whether more than one } \\
\text { method can be used in scientific } \\
\text { research (question } \mathrm{C} \text { ) }\end{array}$ & 69.05 & 7.14 & 4.76 & 19.05 & 100 \\
\hline
\end{tabular}




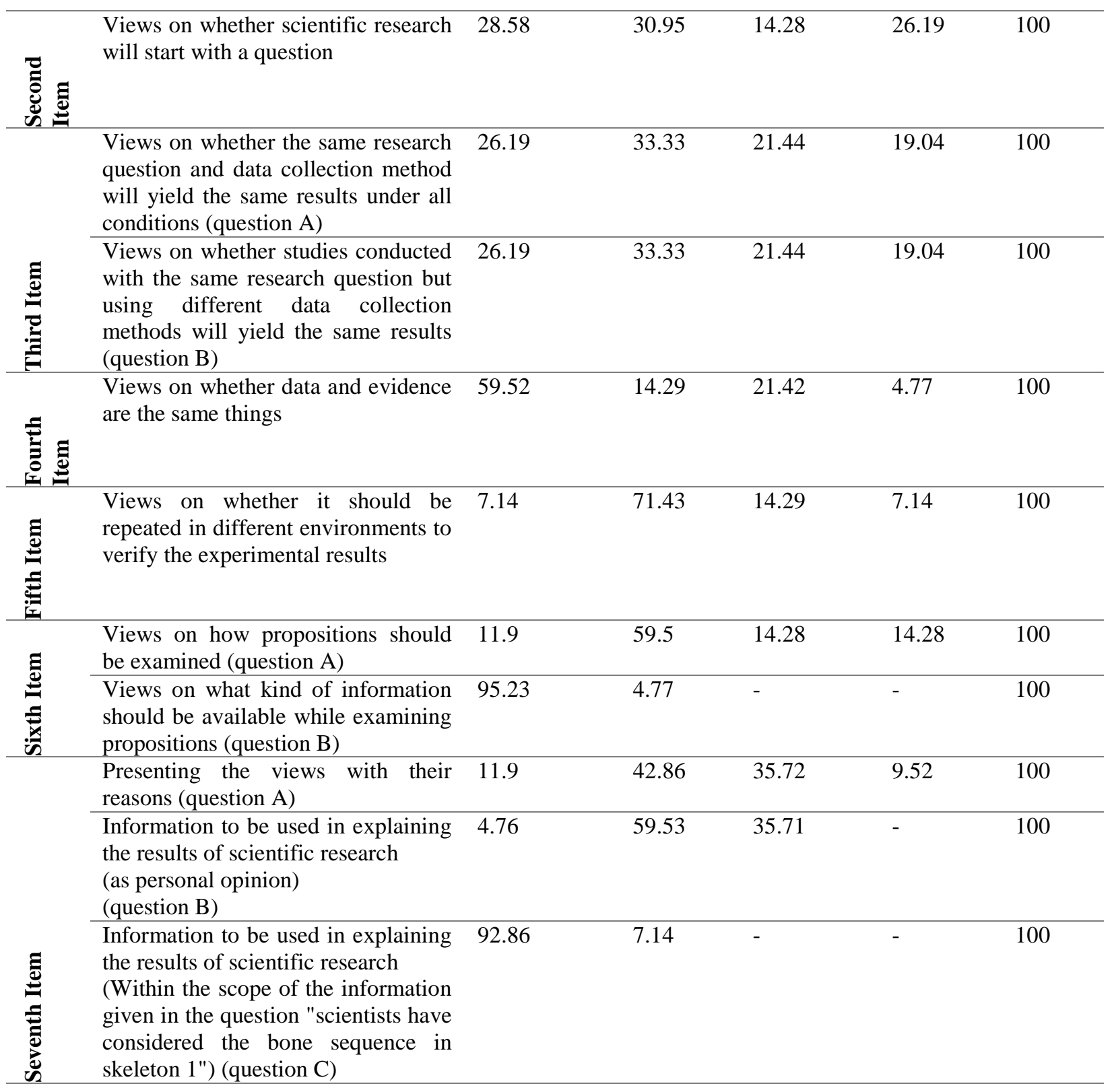

\section{First item}

The first item of the opinion form included a text drawing attention to the relationship between the beak structure of birds and their diet. Based on the content of this text, three questions ( $\mathrm{A}, \mathrm{B}$, and $\mathrm{C}$ ) were asked, and the views of the participants were received. The questions were as follows: A) Is the work done by a person who collects data on the relationship between the beak structure of birds and their diet is scientific research?, B) Is the work done an experiment? C) Can scientific research be conducted with more than one method?

For question A, the majority of the teachers (78.58\%) expressed informed views by saying "it is scientific research"; some teachers $(4.76 \%)$ stated false views by saying that there was no scientific research; some teachers $(7.14 \%)$ stated that they were undecided and expressed naïve views; others $(9.52 \%)$ expressed mixed views by saying that it should be developed in order to be scientific research. Some representative excerpts were as follows: Expressing that the work was scientific research, Özkan from SAU1 University presented an informed view 
by saying "Of course it is scientific. There is a defined purpose and research. It is scientific. Because there is a cause-effect relationship." Illker from MEDU2 University did not answer the question by saying "I don't know much about this issue, to be honest." Although Illker was reinterviewed later, he gave the same answer. Gönül from EAU3 University expressed a naive view by saying "If something is researched, it is scientific." In the first data, Gönül provided an unrelated answer such as "Science is for knowing." Osman from BSU3 University expressed a mixed view by saying "To call research as scientific research, it must be made according to scientific research criteria. Although there are main criteria here, we cannot say that it is a scientific study in the full sense."

The majority of the teachers (95.24\%) gave negative answers to the question B of the first item. For example, Özgür from CAU2 University stated an informed view by saying "Experiment is a complex process performed in order to reach numerical and stable results. The process in this example is not experimental." On the other hand, one teacher $(2.38 \%)$ offered a false view, and one teacher (2.38\%) presented a naive view. Those teachers were Fatma from EAU2 University who expressed naive views by stating "It is not an experiment. If there are no activities carried out in the laboratory environment, it cannot be an experiment." and Derya from AU3 University who presented false view by saying "Yes, it's an experiment. Because an idea is examined, and a result is reached." None of the participants presented any mixed views.

Regarding question $\mathrm{C}$ of the first item, the majority of the opinions $(69.05 \%)$ were that scientific research could be carried out with a single method. Teachers were observed to have false information about the subject. Some teachers (19.05\%) stated that scientific research could be carried out with more than one method. Besides, they supported their opinions with correct examples and had consistent knowledge on the subject. On the other hand, although three teachers (7.14\%) advocated that more than one method could be used, they could not base their statements. Thus, these teachers were considered to have insufficient knowledge. Although two teachers $(4.76 \%)$ were found to have correct information, the research questions they gave as examples were not appropriate. Therefore, they were considered to have mixed views. Gökhan (BSU2 University) expressed his false opinion as "Scientific research refers to one method. Therefore, scientific research should be done with the scientific research method, which is the only scientific method." Sema (SAU2 University) said, "It is important to reach definite results in scientific research. Therefore, the method with proven accuracy should be used while conducting the research." Gökçe (AU2 University), one of the teachers who stated that more than one method could be used, said "There is a mixed research method today. Mixed research is based on pragmatist philosophy. It gathers the needed aspects of all research methods together. Therefore, more than one method can be used in the same research." Gökçe gave the following examples for mixed methods: "I-A study investigating the population growth rate of a city and its reasons, 2-A study investigating the unemployment rate in a city and its reasons." She provided scientific evidence for her research subjects by saying "These are scientific studies that investigate both the phenomenon and its causes together." A similar view was underlined by Sadik from AU1 University. Sad1k put forward his opinion as "More than one method can be used in scientific research if necessary." To support his view, Sad1k presented the following questions: 1- What is the number of rich people in the country? And how did they become rich?, 2- What is the average temperature of the air in the winter months, and what are the reasons? According to him, these questions represent situations that require the use of more than one research method. On the other hand, Cansu (SAU3 University), one of the teachers with insufficient knowledge, used a correct expression by saying "It is possible to use more than one method in 
scientific research." However, her view was considered naive because she did not base her thoughts. Meltem from MU3 University used a consistent statement by saying "Quantitative research and qualitative research methods can be used together in multidimensional research." However, she showed a mixed view on this issue by stating "A study examining under which conditions an egg can be cooked is a study where two methods can be used together."

\section{Second item}

In the second item, their views on the following scenario were examined: Two students were asked whether scientific research would always start with one question. While one of the students approved "yes", the other said "no". Which student do you agree with, why?

The majority (71.42\%) chose the correct answer by stating that they supported the student who said yes. Others $(28.58 \%)$ supported the student who said no and chose the wrong one. Some of those who approved the student who said yes $(30.95 \%)$ had naive views as they could not justify their approval; some $(26.19 \%)$ gave informed views on the subject by providing correct bases; others (14.28\%) showed mixed views by using unclear expressions. The most striking views were as follows:

(Informed) "I support the student who answered yes. Science starts with questioning and trying to find solutions to problems. If a question is not asked (such as how will I solve this problem?), science will not start."(Cengiz from SAU1 University).

(Naive) "I agree with the student who said yes. For example, the question of how we can make our lives better is a scientific question." (Gülşen from EAU3 University). Her example covers a subject that is too wide to be scientific. Because the scope of scientific questions should be determined.

(Mixed) "I agree with the student who said yes. Scientific research always starts by asking a question. However, the aim is not always to answer the question. For example, you want to identify the problem at a school. Your goal is just to determine, not to solve it." (Betül from MU2 University). Talking about the determining nature of science, Betül uses a correct expression. Yet, she is not aware that the determinations made by science are used to solve problems.

(False) "I agree with the student who said no. Because science is born out of necessity. There is no need to ask questions for scientific research. Anyone who wants to build a plane does not ask questions. They think that they need a fast-moving vehicle."(Yavuz from MEDU3 University).

\section{Third item}

The third item involved two questions: A) If many scientists ask the same question and use the same methods to collect data, would they all get the same results?, and B) If many scientists ask the same question and use different methods to collect data, would they all get the same results?

Some teachers $(33.33 \%)$ were found to be oriented toward a strict positivist science paradigm while answering question A. They adopted the experimental research understanding of 
positivism and had naive views because they stayed away from the post-positivist paradigm. On the other hand, other teachers had false views (26.19\%), mixed views $(21.44 \%)$, and informed views (19.04\%). Here some representative examples:

(Informed) "I don't think they can reach because every scientific research carries traces of its researcher." (Tarık from CAU1 University).

(Mixed) "They cannot reach, even if the method and question are the same, every person's thoughts and actions are different." (Selin from AU1 University).

(Naive) "They can reach because scientific knowledge is obtained through experiments. Whenever the experiments are repeated, they give the same result." (Ayşe from SAU3 University). This statement shows that Ayşe has a purely positivist science paradigm. Thus, it would be fair to say that she does not know much about qualitative research.

(False) "I think they can reach. If the road is the same, the method is the same and everything is the same."(Vedat from MEDU3 University). Since Vedat left the answer to this question blank in his opinion form, he was interviewed, and the above answer was received.

Question B shared similar results with question A. While $33.33 \%$ of the teachers had naive views and believed that it could not be reached since they adhered strictly to the positivist view and ignored the post-positivist view, $26.19 \%$ of them said it could not be reached as they had the false information. On the other hand, teachers had false views (26.19\%), mixed views (21.44\%), and informed views (19.04\%). Some striking answers to question B were as follows:

(Informed) "They can be reached. There is not a single way in science. The same result can be reached in different ways." (Gamze from AU2 University).

(Mixed) "They can reach. Maybe it will reach results that can be interpreted differently, but it will reach similar results." (Ömer from EAU1 University). Ömer used this rhetoric during the interview. He made an incomprehensible statement as "There is no real information" in the opinion form.

(Naive) "They cannot reach because real information can be reached through measurement." (İnci from MU3 University). Inci showed that she adheres to the positivist science paradigm by making statements similar to the statements of Ayşe, who graduated from SAU3 University.

(False) "They cannot reach. I think people who use different methods will achieve different results." (Çetin from BSU1 University).

\section{Fourth item}

In this item, the focus was on whether data and evidence were the same concepts, and the answers were asked to be based on examples. While more than half of the teachers $(59.52 \%)$ demonstrated false views, indicating that data and evidence were the same concepts, others $(40.48 \%)$ stated that they were different and showed that they had correct information at this point. The participants who knew the difference between data and evidence $(21.42 \%)$ showed mixed views by partially making the sampling incorrectly, while some of them $(14.29 \%)$ showed naive views by giving completely wrong examples. For example, Ahmet 
from SAU2 University displayed that he knew the difference between data and evidence by saying "Data is raw information, and evidence is information that has been edited and confirmed its accuracy." Yet, he had a naive view on the topic as he said, "Information received from a person is data. Data from a computer is evidence." Hakan (MEDU1 University) presented that he was aware of the difference between the two concepts by emphasizing, "Data refers to the content that has not yet been processed. Evidence is the proven information. They are not the same." However, he was found to have a mixed view: "For example, the presence of light is a proof, but the absence of light is data." This is because he could not explain what evidence of the existence of light might be and to what extent the absence of light was data. Only two (4.77\%) teachers knew the difference between data and evidence and based their views on correct examples at the same time. One of them, Gizem (CAU1 University), made the following statement: "Data and evidence are different from each other. Data refers to information that has not been scientifically revealed and processed. On the other hand, evidence is the information whose certainty has been determined through the data and is ready to be put forward scientifically." She knew the difference between the two concepts correctly and based her knowledge on correct examples. She based her view on the following example: "While raw information obtained in research is data, the constant information obtained as a result of processing this information is evidence." More than half of the teachers (59.52\%) were observed to have false views by saying that data and evidence were the same things. One of them was Sevim from CAU3 University, who said, "Both data and evidence are scientific concepts. Both are included in research lessons. They are the same for me. We can evaluate the result of an experiment as both data and evidence."

\section{Fifth item}

In the fifth item, two groups (A and B groups) were directed the following question: "Are different brands of vehicle tires more prone to bursting?" It was observed that Group A made experiments in one way to find an answer to this question, and Group B made experiments in three different ways. After teachers were informed about this situation, they were asked "Which group gives better results in your opinion? Please explain with its reasons."

While $92.86 \%$ of the teachers chose the correct one by approving Group B, 7.14\% chose the false one by agreeing with Group A. Although the majority of those who approved Group B (71.43\%) used correct expressions by saying that trying different ways would contribute to more consistent results, they did not mention the concepts of reliability and validity. Therefore, they were found to have naive views. For example, Şahin from BSU3 University stated that "I support the method of Group B. Experiments in a single environment may not give healthy results. For this reason, doing it in different environments provides more robust results." Six participants (14.29\%) who favoured Group B argued that the experiments performed in three different ways would provide more concrete information due to the consideration of different environmental conditions. However, it was understood that they had a mixed view because they did not mention the concepts of reliability and validity. For example, Dilek from AU3 University displayed a mixed view on the subject by saying, "I guess Group B will yield more objective results than Group A. The environmental conditions will inevitably affect the content of the experiment. Therefore, experimenting in different environments provides more consistent results." Three participants (7.14\%) answered the question with full knowledge. One of them, Sedat (MU1 University), showed that he had full knowledge of the subject and had an informed view through his following sentence: "I find 
the behaviours of researchers in Group B correct. Scientific investigations are carried out under different conditions to observe whether the results are affected by different conditions and whether different conditions will produce the same results. Such behaviours increase the reliability of scientific research." Kadir from EAU1 University (one of the participants who approved Group A and had a false view) said "I think Group A is right because wherever it happens, the same process gives the same result."

\section{Sixth item}

The sixth item of the form consisted of two questions (A and B questions). Question A included a table showing the relationship between the weekly growth rate of a plant and the daily sun exposure time. The growth rate of the plants was given in inverse proportion to the duration of sunlight. Based on the information presented in the table, participants were asked whether they agreed with the propositions or not. The propositions are as follows: A) The more sunlight, the more plants grow. B) The less sunlight, the more plants grow. C) There is no relationship between the growth of plants and sunlight.

Some participants (11.9\%) showed false views by voicing statements that were not related to scientific research methodology. For example, Ali from BSU1 University demonstrated that he did not know how to approach propositions by saying, "This table is completely wrong. It is known that the sun is necessary for plants." On the other hand, most of the participants $(59.5 \%)$ were found to have naive views on the extent to which the propositions should be resolved. For instance, Mehmet (MEDU2 University) stated that he agreed with the proposition B and stated the reason as "Because the table supports this." Mehmet's view was in line with the necessity of evaluating the propositions within the scope of existing concrete information but was inadequate due to his incomplete explanation. Some participants (14.28\%) made more consistent statements. Although they explained whether they agreed with the propositions or not, they could not make clear enough explanations and showed mixed views. For example, Mahmut from MU1 University said, "Regarding the information of the table, the opposite is the case. Since it will be interpreted according to the information in the table, plants with low light grow more." This statement is correct. While evaluating the propositions, the acquired knowledge is used. However, Mahmut could not adequately explain the reasons for his view. Therefore, his view was considered to be mixed. Other participants (14.28\%) showed informed views. Duygu (MU2 University) explained that she should decide whether to agree with the propositions or not, based on the information presented, together with the reasons, by saying, "According to the table, the longer the sun exposure time, the slower the growth rate of the plants. Therefore, the growth of plants is proportional to whether they get sunlight or not."

In question B of the sixth item, "Do you think the data in the table (the table given in question A) are sufficient for you to evaluate the propositions? Why / why not. Please explain."

All participants responded as yes. The majority of the participants $(95.23 \%)$ used unscientific statements while explaining the reasons for their opinions. Some views were as follows:

(Naive) "I think it is sufficient. The question and the table match. Only the information in the table was asked in the question." (Sevgi from BSU2 University). The participant knew that the proposition should be evaluated within the information in the table, but his explanations were extremely inadequate. Sevgi used this expression during the interview because she did not give clear information in the opinion form. 
(False) "The types of plants should also be given because there are plants that don't need sunlight. "(Zerrin from CAU3 University). Zerrin used this expression during the interview. He expressed an inexplicable expression in the opinion form such as "Plants grow anyway."

(False) "I think water and soil should have been mentioned as well. However, only the sun was mentioned. There is a lack of information. "(Dilek from AU3 University).

\section{Seventh item}

In the seventh item, three questions were asked as $\mathrm{A}, \mathrm{B}$, and $\mathrm{C}$. The questions were prepared according to two dinosaur skeletons. There was a difference between skeletons in the way the front and hind leg bones were placed. In the first skeleton, the big feet are placed in the back, and the small feet are in the front. In the second skeleton, the big feet are placed in the front and the small feet are placed in the back.

In question $\mathrm{A}$, the participants were told that according to most of the scientists the placement in the first skeleton was correct, and then their opinion was asked about this issue. They were also asked to present at least two reasons while expressing their views. Within the scope of the answers, $11.9 \%$ of the participants had false views; $42.86 \%$ had naive views; $35.72 \%$ had mixed views; $9.52 \%$ had informed views. Here are some representative examples:

(False) "I agree with the scientists. 1-) It sounds more logical. 2-) In all known dinosaur fossils, big feet are in the back, small feet are in the front."(Ümit from MEDU1 University). Ümit had a false view as he only decided according to traditional perception.

(Naive) "I believe the first figure is correct. 1) When looking at the skeleton, it seems that the weight should be on the hind legs. 2) The tail is too big. Only big hind legs can lift such a big tail." (Mehmet from EAU2 University). Mehmet made correct explanations but could not explain his findings sufficiently. Therefore, he was assumed to have a naive view.

(Mixed) "The skeleton in the first figure is correct. 1) The environmental conditions in which the dinosaur lived may have required the big feet to be in the back. 2) The body structure of the dinosaur may have required this." (Mert from MEDU2 University). Although Mert's statements were correct, they did not have a scientific basis. In this context, Mert was considered to have a mixed view.

(Informed) "I think the skeletal structure in the first figure is correct. The skeletal structure is shaped by a wide variety of factors. Some examples of these factors can be 1) environment, 2) nutrition style." (Barış from CAU2 University). Barış followed the scientific path, so he was considered to have an informed view.

In question B of the seventh item, participants were asked to answer the following question: "Considering your answer to the above question about placing dinosaur bones, what kind of information do scientists use to explain their conclusions (inferences)?" Two participants $(4.76 \%)$ showed that they had false views by giving extremely narrow answers. Kadir (EAU1 University) gave a simple answer as "If we only think about this question, they use the harmony in visuality-not clear." On the other hand, most of the participants $(59.53 \%)$ answered the question mostly hypothetically. Even though these participants had little knowledge, they did not know enough about the subject, and their views were naive. For example, Cansu from SAU3 University said, "Scientists explain the results with their reasons." Cansu was aware that science is based on the cause-effect relationship, but she 
could not base her opinion on the right foundations. Other participants $(35.71 \%)$, on the other hand, presented mixed opinions. Tark (CAU1 University) said, "They think of many factors together, such as the reasons leading to the conclusion they reached and the way they followed." Tarik's statements were correct. However, he did not explain what he meant by saying "many factors". In this context, he was believed to have mixed information. None of the participants could answer this question with an informed view.

Question C of this article involved "What kind of information do scientists use to explain their conclusions (inferences) while conducting scientific research?" What distinguishes this question from question $\mathrm{B}$ is that it prompted the participants to answer without thinking. However, the majority (92.86\%) did not understand the question and repeated their answers to question B for this question. They were assumed to have false views. Only three participants (7.14\%) did not repeat the answer they gave to question B. However, it was observed that they also had naive views. Here are some representative examples:

(Naive) "They explain it as it is." (Cengiz from SAU1 University).

(Naive) "They use concrete information." (Fatma from EAU2 University).

(Naive) "They use systematic information." (Osman from BSU3 University).

Their responses displayed their consciousness of the fact that science was based on consistency. However, they could not base this knowledge on any grounds.

\section{Discussion and Conclusion}

Social studies course aims to teach the contents of social and human disciplines and methods of reaching the information in accordance with the level of primary and middle school students. In this context, to teach social studies course properly, teachers need to know the methods of reaching the information (that is, scientific research methodology) as well as the content of social studies. Based on this requirement, the study results were discussed and presented below.

Most of the teachers were observed to know the general structure of the concept of scientific research and the basic elements of the experimental process. Teachers' basic knowledge of scientific research can be a result of the lectures given for scientific research methodology, especially during undergraduate education. In their study with student teachers, Akerson and Donelly (2008) found that all participants who took a course on scientific research methodology had basic knowledge in that sense. In this context, the researchers found that the information on the concept of scientific research was mostly acquired during undergraduate education and developed in subsequent processes. Another study supporting this finding is Astor-Jack et al.'s (2007). They examined science education in and out of school within the scope of the views of educators. They found that basic scientific knowledge was gained within the scope of school programs.

More than half of the teachers had false views that speculates a single method could be used in scientific research. In this context, they pointed out only qualitative or quantitative research methodologies, and they were not aware of the mixed-methods research methodology. Although it is basic knowledge that more than one method can be used at the same time in scientific research, it was not valid for the majority of social studies teachers. In this respect, it was observed that the principles of research methods were not at a level, which aretaught to 
students during their undergraduate studies. Examining teachers' views on the epistemology of scientific research methodology, Tsai (2007) also reported that equipping students with correct information could only be achieved with the competence of the teacher. Investigating the content of the scientific research-oriented education given to Brazilian teachers, Monteiro et al. (2016) also stated that students' ability to reach their teaching goals was related to the level of scientific knowledge that teachers have.

Regarding "asking questions", which is the first stage of the scientific research process, most of the participants were found to have false, incomplete or mixed views. Thus, social studies teachers did not know how to start scientific research. Roth et al. (1998) suggested that teachers should concentrate on the content of scientific research in their study in which they investigated how they would teach scientific research to students when they started their profession. Researchers also concluded that student teachers who did not learn much during scientific research-oriented courses would not have sufficient knowledge on the subject.

Regarding whether the same research question and data collection method would give the same results under all conditions, and whether studies conducted with the same research question but using different data collection methods would yield the same results, teachers were found to have false views. Teachers' lack of knowledge about the variables under which research results should be formed was determined as the reason for the errors in their perspectives. In their study examining the views of Korean science teachers about the basis of scientific research, Choi et al. (2019) concluded that most of the participants had sufficient knowledge on the subject, as they took comprehensive courses on scientific research methodology. Many similar studies (Sampson \& Blanchard, 2012; Asay \& Orgil, 2010) reported that science teachers had a high level of knowledge about scientific research, and that they had informed views. Based on the results of these studies, it can be interpreted that the false views of teachers were due to their not taking comprehensive courses on scientific research methodology.

More than half of the participants did not know the difference between data and evidence. This may be due to the insufficient teaching of scientific research methodology in social studies undergraduate programs. Therefore, it is assumed that they will not be able to properly educate students about scientific research methods. According to McNeill and Krajcik (2008), the most influential factors on student learning were teachers' readiness and their practices. Like this study, researchers underlined that the incompetence of the teacher affected students' learning in an absolute way. Flick (2000) concluded that the most important factor in teaching scientific research was the level of knowledge, which shapes the approach towards scientific research.

Regarding the repetition of the results obtained in the experimental procedures under different conditions for verification, participants had false views. Most of the teachers did not know the importance of verification in scientific research, and thus they inconsistently approached the subject. In their study examining the opinions of student teachers on the development of scientific knowledge, Liang et al. (2009) underlined that scientific knowledge was verifiable knowledge and its development could be achieved by testing it under different conditions. This distortion in the views of social studies teachers was identified as another consequence of inadequate training in scientific research methodology in undergraduate education.

More than half of the teachers had naive views about the evaluation process of the propositions and almost all of them did not know what information should be used in the 
evaluation of the proposals. Based on this information, teachers were assumed to be extremely inadequate in teaching the variables of scientific research to students. In their study examining middle school students' views on scientific research, Eliyahu et al. (2020) reported that students with consistent views were students of scientifically equipped teachers, but students with inconsistent views were included in the classes of teachers who did not have sufficient knowledge of scientific research methodology. The findings of Eliyahu et al. (2020) support this study.

Most of the teachers had either naive or mixed views on the necessity of using a basis while expressing an opinion on a scientific issue. The insufficient knowledge of the importance of basing in scientific activities made it difficult for teachers to do scientific research and to teach students how important scientific bases were in research processes. In their study investigating the sources of the problems that primary school teachers experienced while doing scientific research, Cho et al. (2008) reported a lack of justification as one of the reasons for these problems. On the other hand, teachers had false, inadequate or mixed views about the information that could be used in explaining the results of scientific research. How to explain the results of scientific research is very important. Here concrete and understandable expressions are vital and the process followed must be able to be expressed in detail. In this context, having incomplete or incorrect information makes it difficult to understand research results. The teacher who is insufficient in this context will cause his students to be inadequate. Anngraeni et al. (2017) investigated high school students' understanding of scientific research and concluded that the students' level of knowledge on the subject matter was directly proportional to the knowledge level of their teachers.

\section{Recommendations}

The social studies course aims to teach the research methodologies that social sciences use while generating knowledge as well as the information they produce. One of the factors that are necessary for the realization of these goals is that the teacher has sufficient knowledge about the subject. This study found that social studies teachers had false and naive views on the subject matter. It was realized that the reason for the inconsistency in teachers' views was largely related to the education they received. In this context, recommendations were made to teachers, administrators, and the Council of Higher Education (CoHE) officials. Recommendations for teachers are as follows:

- Scientific research is a way to reach scientific knowledge and enough attention should be given to the subject. Thus, the lack of knowledge should be eliminated by reading publications on scientific research methodology and a consistent view should be developed.

- Scientific research trials should be made to obtain information for practice. A collaborative learning approach can be applied by including students in such practices.

Recommendations for administrators:

- In-service training should be provided for teachers' misconceptions about scientific research.

- Teachers should be provided with environments where they can teach their students as well as conduct scientific research.

- Within the scope of a hidden curriculum, teachers should be directed to give more importance to scientific research. 
Recommendations for officials of the Council of Higher Education (CoHE):

- Equally intensive classes on scientific research methodology should be given in all teacher training programs. In this context, comprehensive courses on scientific research methodology should be given in the field of social studies teaching as well as in the field of science teaching.

- Students of social studies teaching programs should be encouraged to do research within the scope of social studies.

- Conducting a scientific study may be required as a condition of graduation from social studies teaching programs.

\section{References}

Akerson, V. L., \& Donnelly, L. A. (2008). Relationships among learner characteristics and preservice elementary teachers' views of nature of science. Journal of Elementary Science Education, 20(1), 45-58. https://doi.org/10.1007/bf03174702

Anggraeni, N., Adisendjaja, Y. H., \& Amprasto, A. (2017). Profile of high school students' understanding of scientific inquiry. In Journal of Physics: Conference Series (Vol. 895, No. 1, p. 012138). https://doi.org/10.1088/1742-6596/895/1/012138

Asay, L. D., \& Orgill, M. K. (2010). Analysis of essential features of inquiry found in articles published in the science teacher, 1998-2007. Journal of Science Teacher Education, 21, 57-79. https://doi.org/10.1007/s10972-009-9152-9

Astor-Jack, T., McCallie, E., \& Balcerzak, P. (2007). Academic and informal science education practitioner views about professional development in science education. Science Teacher Education, 91(4), 604-628. https://doi.org/10.1002/sce.20205

Bianchini, J. A., \& Colburn, A. (2000). Teaching the nature of science through inquiry to prospective elementary teachers: A tale of two researchers. Journal of Research in Science Teaching, 37(2), 177-209. https://doi.org/10.1002/(sici)10982736(200002)37:2<177::aid-tea6>3.0.co;2-y

Büyüköztürk, Ş., Çakmak, K. E., Akgün, Ö. E., Karadeniz, Ş., \& Demirel, F. (2010). Research methods. [Bilimsel araştırma yöntemleri]. Ankara: Pegem Academy Publishing.

Cho, H., Han, I., Kim, H., \& Yang, I. (2008). Analysis of elementary teachers' views on barriers in implementing inquiry-based instructions. Journal of the Korean Association for Science Education, 28(8), 901-921. Retrieved from https://www.koreascience.or.kr/article/JAKO200817347315232.pdf

Choi, A., Seung, E., \& Kim, D. (2019). Science teachers' views of argument in scientific inquiry and argument-based science instruction. Research in Science Education, 1-18. https://doi.org/10.1007/s11165-019-9861-9

Chu, S., Chow, K., Tse, S. K., \& Kuhlthau, C. C. (2008). Grade 4 students' development of research skills through 1nquiry-based learning projects. School Libraries Worldwide, 14(1), 10-37. Retrieved from https://www.iaslonline.org/Resources/Documents/slw/v14/14_1chu.pdf

Crook, C., \& Garratt, D. (2005). The positivist paradigm in contemporary social science research. (Eds. B. Somekh \& C. Lewin). In Research methods in the social sciences, (pp. 207-214). Thousand Oaks: Sage.

Çigdemoglu, C., \& Köseoğlu, F. (2019). Improving science teachers' views about scientific inquiry. Science \& Education, 28, 439-469. https://doi.org/10.1007/s11191-01900054-0 
Eliyahu, E. B., Assaraf, O. B. Z., \& Lederman, J. S. (2020). Do not just do science inquiry, understand it! The views of scientific inquiry of Israeli Middle school students enrolled in a scientific reserve course. Research in Science Education, 1-19. https://doi.org/10.1007/s11165-020-09925-x

Flick, L. B. (2000). Cognitive scaffolding that fosters scientific inquiry in middle level science. Journal of Science Teacher Education,11(2), 109-129. https://doi.org/10.1023/a:1009464707968

Glesne, C. (2016). Becoming qualitative researchers: An introduction. New Jersey: Pearson.

Honebein, P. C. (1996). Seven goals for the design of constructivist learning environments. (Ed. B. G. Wilson). In Constructivist learning environments: Case studies in instructional design, (pp. 11-24). New Jersey: Educational Technology Publications.

Hull, D. L. (2010). Science as a process: An evolutionary account of the social and conceptual development of science. University of Chicago Press.

Hyland, K. (1998). Hedging in scientific research articles (Vol. 54). John Benjamins Publishing.

Jackson, J. (2016). How to develop a research proposal. (Ed. Z. Hua). In Research methods intercultural communication. (pp. 187-202). New Jersey: Wiley Blackwell Puclications.

Kaboub, F. (2008). Positivist paradigm. Encyclopaedia of Counselling, 2(2), 343. https://doi.org/10.4135/9781412963978.n249

Karışan, D., Bilican, K., \& Şenler, B. (2017). Opinion questionnaire about scientific inquiry: adaptation to Turkish, validity and reliability study. [Bilimsel sorgulama hakkında görüş anketi: Türkçeye uyarlama, geçerlik ve güvenirlik çalışması]. İnönü University Journal of the Faculty of Education (INUJFE), 18(1). https://doi.org/10.17679/inuefd.307053

Katz, J. J. (1997). Realistic rationalism. Cambridge: MIT Press

Khishfe, R., \& Abd-El-Khalick, F. (2002). Influence of explicit and reflective versus implicit inquiry-oriented instruction on sixth graders' views of nature of science. Journal of Research in Science Teaching, 39(7), 551-578. https://doi.org/10.1002/tea.10036

Kim, B. (2001). Social constructivism. Emerging Perspectives on Learning,Tteaching, and Technology, 1(1), 16. Retrieved from https://www.semanticscholar.org/paper/FromEmerging-Perspectives-on-Learning\%2C-TeachingKim/159d941e1ae28a612e5a8c3253c56d7626701e50?p2df

Leblebicioğlu, G., Metin, D., Çapkınoğlu, E., Çetin, P. S., Eroğlu, D. E., \& Schwartz, R. (2017). Changes in students' views about nature of scientific inquiry at a science camp. Science \& Education, 26(7-9), 889-917. https://doi.org/10.1007/s11191-0179941-z

Lederman, J. S., Lederman, N. G., Bartels, S. L., \& Jimanez, J. P. (2019). Understandings of scientific inquiry: An international collaborative investigation of grade seven students. Bridging Research and Practice in Science Education, 189-201. https://doi.org/10.1007/978-3-030-17219-0_12

Lederman, J. S., Lederman, N. G., Bartos, S. A., Bartels, S. L., Meyer, A. A., \& Schwartz, R. S. (2014). Meaningful assessment of learners' understandings about scientific inquiry-The views about scientific inquiry (VASI) questionnaire. Journal of Research in Science Teaching, 51(1), 65-83. https://doi.org/10.1002/tea.21125

Liang, L. L., Chen, S., Chen, X., Kaya, O. N., Adams, A. D., Macklin, M., \& Ebenezer, J. (2009). Preservice teachers'views about nature of scientific knowledge development: An international collaborative study. International Journal of Science and Mathematics Education, 7(5), 987-1012. https://doi.org/10.1007/s10763-008-9140-0 
Luehmann, A. L., \& Markowitz, D. (2007). Science teachers' perceived benefits of an out-ofschool enrichment programme: Identity needs and university affordances. International Journal of Science Education, 29(9), 1133-1161. https://doi.org/10.1080/09500690600944429

Matthews, M. R. (2012). Changing the focus: From nature of science (NOS) to features of science (FOS). In Advances in nature of science research (pp. 3-26). Springer, Dordrecht.

McNeill, K. L., \& Krajcik, J. (2008). Scientific explanation: Characterizing and evaluating the effect of teachers' instructional practices on student learning. Journal of Research in Science Teaching, 45(1), 53-78. https://doi.org/10.1002/tea.20201

MEB (2018). Social Studies 4, 5, 6, \& 7th classes curriculum. [Sosyal Bilgiler 4,5,6 ve 7. sinıf programı]. Ankara: Presidential of Training \& Discipline.

Monteiro, B. A. P., Martins, I., de Souza Janerine, A., \& de Carvalho, F. C. (2016). The issue of the arrangement of new environments for science education through collaborative actions between schools, museums and science centres in the Brazilian context of teacher training. Cultural Studies of Science Education, 11, 419-437. https://doi.org/10.1007/s11422-014-9638-4

Onwuegbuzie, A. J., \& Leech, N. L. (2007). Sampling designs in qualitative research: Making the sampling process more public. Qualitative Report, 12(2), 238-254. https://doi.org/10.1007/s11135-006-9000-3

Park, Y.-S. (2010). Secondary beginning teachers' views of scientific inquiry: With the view of hands-on, minds-on, and hearts-on. Journal of the Korean Earth Science Society, 31(7), 798-812. https://doi.org/10.5467/jkess.2010.31.7.798

Patton, M. Q. (1990). Qualitative evaluation and research methods. Thousand Oaks: Sage.

Ravetz, I. R. (1999). What is post-normal science. Futures the Journal of Forecasting Planning and Policy,31(7), 647-654. Retrieved from http://www.andreasaltelli.eu/file/repository/Editorials2.pdf

Roth, WM., McGinn, M.K. \& Bowen, G.M. (1998). How prepared are preservice teachers to teach scientific inquiry? Levels of performance in scientific representation practices. Journal of Science Teacher Education 9, 25-48. https://doi.org/10.1023/a:1009465505918

Russell, B. (1935). Religion and science. London: Oxford University Press.

Sampson, V., \& Blanchard, M. R. (2012). Science teacher and scientific argumentation: trends in views and practice. Journal of Research in Science Teaching, 49(9), 11221148. https://doi.org/10.1002/tea.21037

Stokking, K., Schaaf, M., Jaspers, J., \& Erkens, G. (2004). Teachers' assessment of students' research skills. British Educational Research Journal,30(1), 93-116. https://doi.org/10.1080/01411920310001629983

Şenler, B. (2015). Middle school students' views of scientific inquiry: An international comparative study. Science Education International, 26(2), 166-179. Retrieved from https://eric.ed.gov/?id=EJ1064039

Tsai, C. C. (2007). Teachers' scientific epistemological views: The coherence with instruction and students' views. Science Education, 91(2), 222-243. https://doi.org/10.1002/sce.20175

Wahbeh, N., \& Abd-El-Khalick, F. (2014). Revisiting the translation of nature of science understandings into instructional practice: Teachers' nature of science pedagogical content knowledge. International Journal of Science Education, 36(3), 425-466. https://doi.org/10.1080/09500693.2013.786852

Wilson, E. B. (1990). An introduction to scientific research. Massachusetts: Courier Corporation. 
Yu, J. C., \& Yang, H. J. (2010). Incorporating museum experience into an in-service programme for science and technology teachers in Taiwan. International Journal of Technology and Design Education, 20(4), 417-431. https://doi.org/10.1007/s10798009-9101-0 